\title{
Taevasest üliolendist usundilooliselt ja muinaseesti aineses
}

\author{
Tarmo Kulmar
}

\begin{abstract}
Teesid
Põhiliste religioonifenomenoloogiliste printsiipide järgi elab üliolend taevas või on ise taevas. Ta on kõikvõimas looja, kellel on tihti ka äikesejumal funktsioon. Tema nimi on kas Isa või Vanaisa. Talle tuuakse esmikohvrit ja ta on kujunenud deus otiosuseks.

Keeleajaloolased on seisukohal, et balti-läänemeresoome ja eesti ülijumala mõiste pärineb soome-volga keelekihistusest, arheoloogilises terminoloogias neoliitikumist (3. aastatuhat $\mathrm{eKr}$ ). Selle tunnistuseks on eesti keeles eesti sõja juma(l), mis algselt tähendas taevast, aga ka indoeuroopa laensõna taevas. Ülijumala ja äikesejumal Uku või Ukko lahknemine toimus ilmselt esimesel aastatuhandel eKr. 13. sajandil kirja pandud Henriku Liivimaa kroonika ja teiste kroonikate järgi on Eesti rannikul kutsutud äikesejumalat ka Taaraks või Tooruks, millel võib olla seoseid muinasskandinaavia Thoriga.
\end{abstract}

Märksõnad: balti hõimud, balti keeled, eesti arheoloogia, eesti muinasusund, läänemeresoome hõimud, läänemeresoome keeled, Taara/Tooru, Uku/Ukko, äikesejumal, üliolend/ülijumal

\section{Üliolend kui fenomen}

Seda, kuidas üliolendit (ülijumalat, hilisemat deus otiosust) ja temaga seotud nähtusi kirjeldada, on kõige parem tundma õppida tänapäeva loodusrahvaste etnoloogilise ainese põhjal, mida on viimase kahe sajandi jooksul kogunenud tohutu hulk. Eriti väljapaistev on selles vallas muidugi Wilhelm Schmidt oma põhjapaneva suurteosega Der Ursprung der Gottesidee. Eine historisch-kritische und positive Studie (vt sh Schmidt 1935) ja hilisemate autorite tööd vaid kinnitavad seda.

Üliolend on seotud taevaga: ta elab taevas või on ta ise taevas. Taevakehad (Päike, Kuu, tähed) on tema silmad ja kõrvad (Herrmann 1961: 65). Taevakujutlustega on üliolend seotud ka kõrgkultuurides (Hiina Shang-di, Polüneesia Tangaroa, mongoli Tengri, sumeri

http://haldjas.folklore.eeltagused/nr30/kulmar.pdf 


\section{Tarmo Kulmar}

An, maiade Itzamna, inkade Wiracocha) (Achelis 1919: 9). Taevajumalast üliolendit kujutatakse äikesejumalana: Malai semangidel on äike ja üliolend mõlemad Karei (Schebesta 1927: 271). Andamaanide Paluga hääl, tuul ja hingus on äike, aga välguga karistab ta inimesi. Keenia dšaggadel on välk ülijumala kirves. Tihti on ka vikerkaar ülijumala eriline manifestatsioon ja koguni temaga identne, näiteks Zimbabwes (Herrmann 1961: 67). Ülijumalat kujutatakse ette heleda valguskujuna, aga ka valguseandjana (Heiler 1979: 456). Ta võib olla ka antropomorfsete joontega (vanamees, halli habemega hiiglane vms). Selles seoses on üliolendil ka vastavad nimed: Isa, Minu Isa, Meie Isa, Ürgisa, Ürgvana, Vanamees, Vanaisa (Heiler 1979: 456). Ent osa nimesid viitab üliolendi funktsioonidele: Looja, Tegija, Vägi jne. Jorutadel on nimeks Iseolev, asteekidel See, Kes End Ise Välja Mõtles. Muide see, et üliolendit Isaks nimetatakse, ei tähenda, nagu oleks ta inimsoo esiisa ja seotud seega esivanematekultusega - tegemist ei ole manistliku olendiga (Herrmann 1961: 67).

Inimeste esiisa on loonud üliolend. Seega on üliolend eelkõige Looja, igavene ürgalge. Ka nimed Omanik, Surmaja, Elu Isand, Seaduseandja, Ürgliikumapanija jt osutavad üliolendi kui J u m a 1 a funktsioonidele, selle olendi absoluutsele vägevusele maailma ja inimeste suhtes (Heiler 1979: $456 \mathrm{jj}$ ). Juhtub ka, et üliolend on Nimetu. Temasse, ta nimesse ja asukohasse suhtutakse suure aukartusega. Enamasti kujutletakse teda vallalisena, kuigi mõnedel rahvastel on tal ka naine ja poeg, kusjuures viimane on siis inimsoo esiisa (Austraalia kurnaid). Reeglina on üliolend meessoost, naisena esineb ta üksikuil juhtudel (Kolumbia kagabad), siis kutsutakse teda ka Esmasünnitajaks. Harva esineb kujutlus kahesoolisest üliolendist (Dahomee Nana Buluku), kes võib soovi korral sugu vahetada. Üliolend on tihedasti seotud väe või elujõu ideega. Olgu tegu apatšide digi, siuude wakonda, eskimo sila või mõne muu animistliku väe nimetusega, on nad ikkagi mingil viisil ühenduses üliolendiga (Herrmann 1961: 70).

Ülijumala iseloomulikumaid jooni on aga tema eemalviibivus. Üldlevinud on arvamus, et deus otiosuseks on üliolend muutunud hiljem, kui tema austamine on teiste jumaluste, kultuste ja riituste esiplaanile nihkumisel varju jäänud. Mircea Eliade nimetab seda isegi ülijumala religioosse väärtuse kaotamiseks (Eliade 1992: 67), millega küll ei saa nõus olla: kuigi üliolendi kujutlusega ei kaasne kultust (ja ilmselt puudus see reeglipärasena ka algselt, sest loo- 


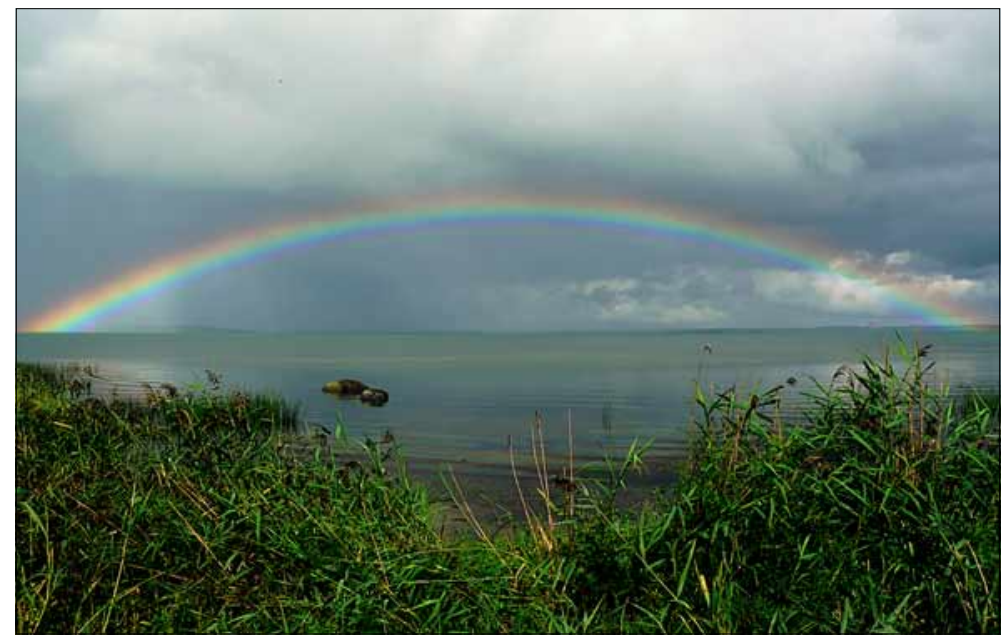

Foto 1. Paljud rahvad on pidanud vikerkaart üheks ülijumala manifestatsiooniks, sillaks teispoolsusse või äikesekuninga vööks. Vikerkaar Saaremaal Kaalis augustis 2005. Andres Kuperjanovi foto.

dusrahvastel on üliolendiusk ikka veel elav) ja mitmesugused loodususundilised või polüteistlikud kultused on pidevalt käepärast, pöördutakse v i i m a s e s h ä d a s siiski tema poole. See asjaolu on just vastupidi M. Eliade väitele märgiks, et üliolendi religioosne väärtus on kõige suurem.

Küll on M. Eliadel õigus selles, et üliolendikujutlustel pole enamasti kohta ka müütides - ta on suuremal või väiksemal määral müüdivaba (Eliade 1992: $67 \mathrm{jj}$ ). Sellele pealtnäha uskumatuna tunduvale asjaolule juhtis tähelepanu juba Leopold von Schroeder, mööndes, et ainsad müüdid üliolendi kohta on seotud tema funktsiooniga loodus- või hingejumalana (Schroeder 1914: 578 jj). Mis üliolendi kultusesse puutub, siis see teatud viisil ikkagi eksisteerib. Klassikaline on Paul Schebesta semangide Karei või Ta Pedniga seotud asjaolude kirjeldus, kus toonitatakse esmikohvrit ja pühendamistseremooniaid (initsiatsiooni) (Schebesta 1927: $249 \mathrm{jj}$ ).

Üliolendi poole loomulikult palvetatakse. Tulemaa jaganidel tuntakse Watauineva poole pöördumist tänu-, palumis- ja kaebuspalve vormis. Üliolendit kujutletakse mittevaimsena, kuigi mitmetel Aafrika, indiaani ja arktilistel hõimudel esineb ka väega samastamist. Et üliolendi kõrval kohtab alati teisi jumalusi, ei saa 


\section{Tarmo Kulmar}

rääkida loodususundilisest monoteismist. Küll aga on rahvastel, kus üliolend on harvades müütides loonud teised jumalused, tegemist ebapuhta monoteismiga (Herrmann 1961: 73-74).

Rahvastel ja usundites, kus vähemal või suuremal määral kohtab üliolendi samastamist päikese, looma või linnuga, on ilmselt täheldatav ülijumala otioseerumise protsess ja polüteistlike kultuste formeerumine. Selliseid näiteid leidub nii usundiloos kui ka tänapäeva loodusrahvaste usundites. Apatšidel ja siuudel on päike üliolendi asupaik, Keenia dšaggadel on küll üliolendi ja päikese kohta üks ja sama sõna, kuid nad ei ole tähenduselt üks ja sama. Paljud Austraalia hõimud austavad päikesetõusu kui ülijumala loomisväe allikat. Ka kirgiiside juures läheb noorpaar pärast pulmaööd pidulikult päikest tervitama.

Algelistel maaharijatel on päike üliolendi väe kehastusena oluline viljakuskultuses, näiteks hopi- ja puebloindiaanlastel. Üpris tihti esineb kujutlus, et päike ja kuu on üliolendi silmad ja kõrvad (vedade tekstides on päike Taeva silm, Jaapani ülijumala Izanagi vasak silm on päike, parem aga kuu). Nn arhailiste kõrgkultuuride dualismis ja viljakuskultuste levikuga seoses leiab aset ühelt poolt Taeva ja Maa kui viljakuspooluste vastandamine, teiselt poolt aga see, et päike ja kuu muutuvad üliolendi hüpostaasideks. Huvitav on märkida, et kuu on mehe ja päike naisena tuntud indoeurooplaste (baltlaste), türgi rahvaste, paleoasiaatide, semiitide ja mõnede troopilise Aafrika hõimude juures. Ülejäänud piirkondades (Lõuna- ja Ida-Aasias, Ameerikas, Okeaanias, suures osas Aafrikas, muide ka Egiptuses) esineb mehena päike ja naisena kuu (Herrmann 1961: 75-83).

Ei ole teada, kas üliolendikujutlused olid ürgajal seotud loomadega. Tänapäeva algastmel seisvate kultuuride puhul kohtab seda harva, üliolendil on pigem inimlikud jooned. Muutus tuleb kütikultuurides, kus esineb rohkesti totemismi. Kui kõik olendid arvatakse mingil moel loomadega seotud olevat, kehtib see ka üliolendi suhtes. Omahaindiaanlastel eksisteerib koguni loomade koosolek, kus arutatakse, kuidas inimesi aidata. Vaid Wakonda on neist kõrgemal. Loomadega on seotud ka taevakehad, koguni taevas: ka tähtkujud paistavad ju kätte loomadena. Sama lugu on bušmanitel, Brasiilia hõimudel, evenkidel. Üliolendil on neis kultuurides loomade isanda (harvem loomade emanda) funktsioonid. Ka loomade isand näeb sageli välja inimkujuline, kuid on kas iseäraliku suurusega või leidub tal teistsuguseid jooni (heledus, nahavärv vms). 
Et loomade isandal on abiks mitmesuguseid kaitsevaime, on sellised haldjad sageli ka tema kui üliolendi loodud. Aafrikas on loomade isandaid ka loojatena ette kujutatud (Herrmann 1961: 86-91).

Paljudes kultuurides seostatakse üliolendit lindudega. Siin on ilmselt samuti tegemist kütikultuuride totemistliku ajajärguga.

Eriti levinud on kotka pidamine lindude kuningaks - kotkas on seotud eelkõige taeva, äikese ja päikesega. Muistsete kreeklaste ja roomlaste kujutlus, et kotkas elab jumalate juures (Zeus võib teriomorfselt kotkas olla, näiteks Ganymedest röövides), esineb ka loodusrahvastel. Kotkas on üliolendi saadik Nigeeria ibibodel, Põhja-Ameerika indiaanlastel on kotkas äikeselinnuks (šoniid ehk rebased ehk foxindiaanlased peavad välke taevakotka sabasulgedeks). Jakuudid seostavad kotkast kui võimsuse ja tule sümbolit päikesega. Teistelgi paleoasiaatidel seostatakse üliolendit kotkaga - ta võib võtta kotka kuju või on kotkas tema püha lind. Kotkas võtab osa loomisest: jakuutide ja soomlaste loomismüütides muneb kotkas maailmamuna. Burjaadid peavad kotkast esimeseks šamaaniks, nagu handid ja mansidki. Mandžud peavad patuks kotkast tappa. Ainudel on kotkas looja, hopiindiaanlastel kattub üldse üliolendiga. Kesk-California hõimudel on kotkas loomade koosoleku juhataja ning üliolendi ja inimeste vahendaja. Sageli võitleb kotkas ürgkurjusega (asteekidel, burjaatidel), olles päikese sümbol. Mõnikord on ta ka tuletooja (Herrmann 1961: 91-96).

On peetud võimalikuks, et üliolendikujutlused on tekkinud kristlike misjonäride mõjustusel, mis mitmetel juhtudel pole ilmselt ka võimatu.

Kokkuvõtteks. Ülijumala- või üliolendikujutlusi kohtab üle kogu maailma väga paljude loodusrahvaste juures. Nende olemasolu täheldatakse ka kõrgkultuuride mittemonoteistlike usundite varastes kihtides - mida kaugemale minevikku, seda selgemalt. Teisalt, mida algelisemal kultuuriastmel on tänapäeva loodusrahvad, seda tugevamad on nende juures üliolendikujutlused. Alati on üliolendit (mitte aga äikesejumalat, kes võib selleks muutuda sekundaarselt) kujutletud suuremal või vähemal määral otioossena, seotuna taeva, äikese ja teiste ilmastikunähtuste ning taevaste valgusallikatega, totemistlikes kultuurides loomade isandaga, väga sageli kotkaga. Ta on looja, kuid mitte inimsoo esiisa, teda kujutatakse kõige sagedamini vanamehena, keda ümbritseb hele valguskuju, tal on nimi, mis kajastab tema olemust, funktsioone ja vägevust, ta on seotud väekujutlustega või on ise vägi, ta on enamasti müüdivae- 


\section{Tarmo Kulmar}

ne, ta on andnud inimkonnale eetilised printsiibid ja nõuab nendest kinnipidamist, teda kummardatakse ja austatakse, aga ei teenita kultuslikult. Siiski on ta põhiolemuselt materiaalne, spirituaalne substants. Kultuse ja spirituaalsuse puudumine ongi võib-olla ainsad fenomenoloogilised jooned, mis eristavad kujutletud üliolendit Jumalast.

\section{Läänemeresoome ja eesti hõimude taevane üliolend}

Üliolendikujutluste esinemine kogu maailma loodusrahvaste juures, samuti väga tõenäoline olemasolu esiajalooliste rahvaste usundites hiljemalt alates neoliitikumist sunnib arvama, et see olend pidi eksisteerima ka eesti muinasusundis, kuigi selle kohta tundub olevat väga vähe andmeid.

Eesti sõna jumal pärineb keeleajaloolaste üksmeelse arvamuse kohaselt soome-volga keelekihistusest (Rédei 1986-1991: 638; Mägiste 1982-1983: 567-568), seega arheoloogilises mõttes nooremast kiviajast. Algselt on sellega tähistatud taevast. Niisiis on tegemist taeva kohta käiva omasõnaga. Et kõikide rahvaste juures on taevast võrdsustatud üliolendiga (tundub, et see on religioonifenomenoloogiline reegel), peaks see asjaolu lubama väita taevajumala olemasolu ka muistsete eestlaste usundis.

Tahtmata ületähtsustada ilmasamba ja maailmapuu sümboolikat, tuleb siiski nõustuda M. Eliadega selles, et ilmasamba kujutlused (muidugi eri vormides) on usundites üldtuntud (Eliade 1992a: 58) ja on täiesti võimalik, et selle sümboolika on seotud nii viljakuse kui ka taevaga (Eliade 1987: 156), olgu siis põhjaeuraaslastel või indoeurooplastel, kaugematest rahvastest kõnelemata. Ilmasambast kui kahte ilma (maad ja taevast) ühendavast usundilisest elemendist kirjutab Oskar Loorits: ilm on tähendanud üheaegselt maailma, taevast ja tuuli (Loorits 1949: 399 jj). Kui Ilmari (Ilmarinen) võis hilisemal ajal, vähemalt Soomes, olla taevajumala nimi (Loorits 1949: 400; Sayers 1990: 111; Lanczkowski 1989: 107), siis taevane üliolend pidi kandma seda nime võrdlemisi kauges minevikus. Uku Masing leiab küll, et Eesti usundiaines sellenimelist taevaolendit ei tunne (Masing 1995: 49-50). Folklooris tuntakse ilmaneitseid, kuid need seisavad kuidagi omaette ega tarvitse üldse üliolendiga seotud olla (Masing 1995: 37). Sõna ilm on oletatavasti soome-ugri 
keelekihti kuuluv tähistus (Mägiste 1982-1983 II: 501-503; Rédei 1986-1991: 81).

Kui arvestada, et üliolendit kutsutakse Isaks või Vanaisaks (selline nimetus on levinud ka Eestis, nagu näitab Masing 1995: 3940), siis juhul, kui üliolendikujutlus võiks ulatuda veelgi varajasemasse aega, aitaks seda kaudselt kinnitada sõna isa uurali päritolu (Mägiste 1982-1983 II: 517; Rédei 1986-1991: 78). Samast kihist tuleb ka sõna ime (Mägiste 1982-1983 II: 506; Rédei 1986-1991: 82): kõik väljaspool inimese mõistmise piire seisev pidi olema ime ja seega midagi sellist, mis kuulub üliolendi toimimissfääri. Et üliolend asus taevas, seega ülal, võiks ka sõna üla- ulatumine uurali kihti (Rédei 1986-1991: 573) aidata kaudselt toetada uurali usundikihi üliolendikujutluse olemasolu. See on muidugi võrdlemisi ebakindel oletus.

Üliolend on seotud loomisega. Sõna looma kuulub soome-ugri kihti. Ent sisuliselt samatähenduslik on ka sõna algama, mis tundub olevat veelgi vanem: Julius Mägiste (1982-1983 I: 60) järgi on see sõna pärit soome-ugri kihist, Karoly Rédei (1986-1991: 6) kahtlustab aga koguni uurali päritolu.

Mingisugune seos nimetatud mõistetega tundub olevat ka sõnal sugu, soome suke-, millel J. Mägiste (1982-1983 IX: 2895) leiab küll olevat saami algupära, mis aga Jorma Koivulehto järgi võib minna varajaste indoeuroopa kontaktideni: < soome-ugri *suke < indoeuroopa *suH, vrd vanaindia sute, passiivis suyate - sünnitud saama, tekkima (Koivulehto 1991: 69). Üliolendi taevane lind on tihti kotkas, mida tähistaval sõnal on samuti ürgne, kas soome-permi (Rédei 1986-1991: 668) või soome-ugri (Mägiste 1982-1983 III: 969) päritolu. Vikerkaart on läänemeresoome mütoloogias käsitletud kui pikse ambu (Loorits 1951: 31; Masing 1995: 34-35). Ent kaar ulatub samuti tagasi võib-olla isegi uurali kihti (Rédei 1986-1991: 126). Kui üliolendiuskumused sellal olemas olid, kuulus selle juurde kindlasti ka ju äikesega seotud funktsioon.

Igal juhul usub ka Oskar Loorits, et taevavaimukujutlus ulatub tagasi vähemalt permi või isegi varasemasse aega (Loorits 1951: 5). Taeva hingus on tuul -sõna pärineb soome-permi (Rédei 1986-1991: 800) või soome-ugri ajast (Mägiste 1982-1983 X: 3386) ja see asjaolu võib olla veel üheks üliolendiusu kaudseks kinnituseks. J. Koivulehto meelest võib tuul küll taas olla uurali kihistuse aegne indoeuroopa laen: $<$ uurali $*$ tuxli < indoeur. ${ }^{*} d^{h} u H$-li, juure $* d^{h} e w H$ tuletis - sööstma, keerlema, puhuma; hingus (Koivulehto 1991: 65). 


\section{Tarmo Kulmar}

Taeva ja algselt võib-olla juba taevase üliolendi omatähistuseks on olnud, nagu eespoolgi viidatud, sõna juma(l), mis läheb tagasi soome-volga aega. Nagu O. Loorits arvab, on juma esialgu tähendanud kaant, kuid ta võib olla ka aarja laensõna. Jumale on pakutud mitmeid etümoloogiaid, sh ka seoses hämaruse ja pilvede kui taevast katva või kattevarjust välja kooruva jumalaga (Loorits 1949: 392). Isiklikult on O. Loorits seisukohal, et jumi on 'nägu', seega taevakaas oleks elava taeva nägu - jume. Sõna juma (jumi) peaks olema seega taeva omanimi (Loorits 1949: $393 \mathrm{jj}$ ).

Uku Masing (1995: 43-44) annab veelgi ilusama tähenduse-pale. Edasi eristab O. Loorits juma eri kasutusviise eestlastel ja soomlastel: eestlane pöördub juba muistsest ajast üttena aita, juma (aita, taevas), jumal appi (taevas appi), tere jumalime (tere taeva nimel), samal ajal kui soomlastel jääb jumi seotuks irdhinge- ja surnukultusega (Loorits 1949: 398). Teisalt peaks juma(l) tähendama kaitsevaimu üleüldse - taevast kaitseolendit (Loorits 1949: 587). Samas ei välista O. Loorits võimalust, et juma võib olla tähendanud ka analoogiliselt indoeuroopa deiwosele hiilgav (Loorits 1949: 398), kuigi tundub, et ta sellist seletuskatset heal meelel ei tunnista, sest see tähendaks tema meelest indoeuroopaliku dualismi liiga varajast sissetulekut.

Süvenemata rohkem juma(la) võimalikesse etümoloogiatesse, võime $\mathrm{O}$. Looritsa eeskujul jääda seisukohale, et juma(l) vahetas taevase üliolendi omanimena soome-volga ajastul välja ilma, mis on võinud vähemalt sõnavara ajalugu arvesse võttes tähistada taevast või taevast üliolendit soome-ugri või koguni uurali ajastul.

Mõneti sekundaarseks probleemiosaks antud käsitluses on mõistatuslikuks jäänud Jumi küsimus, mida siiski mõne sõnaga vaadelgem, sest muidu võib tekkida eksitavaid paralleelitõmbamisi jumi / juma(la)ga.

Juba L. von Schroeder on seoses eestlaste folklooris esineva taevapulma ja Salme müüdiga nimetanud Jumi-pulmi (von Schroeder 1914: 392 jj). Rohkem esineb seda mütoloogilist nähtust Soome ja Karjala 17.-18. sajandi allikates, kuid ka Põhja-Eesti toponüümikas, näiteks Jumindat on 1290. aastal nimetatud Jumentake, mida Felix Oinas etümologiseerib Jumin takana (Oinas 1981: 256). Jumi vasaraks (Jumin kurikka) on nimetatud fallost, väljend Jumi juurde magama minema on tähendanud armuakti. Võttes arvesse Leedu materjali, peab F. Oinas seda võrdlemisi hiliseks balti või germaani viljakuskultuslikuks laenuks (Oinas 1981: 256-261), mis jääb 
käesoleva kirjutise raamistikust välja ja mida ei saa siinkirjutaja meelest juma(la)ga kuidagi ühendusse viia.

Kui soome-ugri rahvad jõudsid Baltikumi, laenasid nad, kui lähtuda Paul Ariste seisukohast (Ariste 1981: 20 jj), kohalikust substraatsest keelekihistusest sõna taevas. Nimetatud seisukoha järgi on taevas laen substraatkeelde satem-rahvastelt ning tähistab indoeuroopa taevast ülijumalat, kuuludes deiwos / dyews'-ritta. Nii O. Loorits (1949: 398) kui ka hiljem Lembit Vaba (1993: 508) peavad sõna taevas küll indoeuroopa algupäraga balti laenuks, ent siinkirjutaja eelistab P. Ariste seisukohta, sest esiteks võib satem-hõimude kokkupuude substraatkultuuriga arheoloogia andmeil olla tõenäoline ja teiseks võisid protobalti hõimud jõuda Baltikumi mitte nöörkeraamikakultuuri, vaid järgmise indoeuroopa lainega. Indoeuroopa taevajumalakujutlusega pidid Kunda ja Narva kultuuri kandjad kokku puutuma seega varem - kas satem- või nöörkeraamikakultuuri vahendusel.

Kas soome-ugri eelne substraatkultuur tundis ka varem ülijumalakujutlust? Kui substraadiga üheaegne uurali ja soome-ugri rahvastik Ida-Euroopas seda põhimõtteliselt tundis, ei ole see võimatu ka substraadi puhul. Ülijumalakujutlus tekib ilmselt kõikidel rahvastel. Muidugi olid ilmselt veel valdavad mitmesugused väekujutlused, kuid ülijumala algmed võisid juba olemas olla, neid aitas süvendada ja kiirendada kokkupuude satem-hõimudega ja taeva mõiste laenamine jumalanimena. Ka U. Masing arvab, et algselt tähendas taevas nii taevast kui ka ülijumalat (Masing 1995: 18), ka sumeri an on tähendanud nii ühte kui ka teist. Kui selle sõna laenasid nüüd soomeugrilased, siis kujunes ajapikku mõistete lahknemine: taevas hakkas tähendama loodusnähtust ja juma(l) muutus üliolendi tähistuseks.

\section{Äikesejumal}

Henriku Liivimaa kroonikas juhitakse korduvalt tähelepanu saarlaste ja muhulaste, kuid ka põhjaeestlaste jumalale Tharapitale või Tarapithale, keda enne lahingut palutakse (Henrik 1982: XXIV, 5; XXX, 5). Saarlaste suur jumal olevat sündinud Ebavere mäel ja lennanud sealt Saaremaale. Thomas Hiärne kirjutab 17. sajandil kõuejumalast, keda kutsutakse Vanaisaks: soome ucko jürisep ehk eesti 'kou mürisep' tähendas Vanaisa müristamist. Esmakordselt püsti- 


\section{Tarmo Kulmar}

tab just T. Hiärne oletuse, et siin võib olla tegemist Skandinaavia Thori kajastusega (Hiärne 1963: 73-74).

L. von Schroeder arutles selle probleemi üle põhjalikumalt eelmise sajandi alguses. Mainides äikesetrummi kui müristaja Pikset, keda nimetatakse ka Kõueks, Kõuetaadiks, Müristaja-taadiks, peab ta teda eestlaste äikesejumalaks. Samuti nimetab ta eestlaste peajumalana Taarat kui teisendvormi Tarapithast (Taevaisast), arvates sel olevat lähedasi seoseid Thoriga. Et Lääne-Eestis on armastatud neljapäeva pühitseda, võib see samuti viidata Thori kultusele. Erinevalt Nikolai Andersonist ei nõustu L. von Schroeder arvamusega, et Taara võib tuleneda handi-mansi Numi-Torumist, vaid pigem Thorist (Schroeder 1906: 83-88). Kümmekond aastat hiljem nimetab ta Ukkot samuti eesti-soome peajumalaks (Schroeder 1914: 530), kuid ei välista täielikult seoseid ka Numi-Torumi hüpoteesiga - obi-ugri rahvad võisid olla laenanud selle Iraanist või Indiast, eestlased aga Skandinaaviast (Schroeder 1914: 613-618).

Numi-Torumi ja Taara seoste vaatlemise võime tänapäeval ilmselt rahulikult kõrvale jätta, kuid seoseid Thoriga tuleb nähtavasti mingil määral arvestada. Loomulikult ei tohi probleemi lihtsustada ja väita, nagu oleksid muinaseestlased viikingiajal Thori kultuse lihtsalt üle võtnud, kõnelemata sellest, nagu kujutaks Ukko või Taara endast ka äikesejumalakujutlusena laenu.

Kui saame võrdlemisi tõenäoliselt oletada üliolendi austamist soome-volga perioodil, võimalik aga, et juba veelgi varajasematel perioodidel, ei tohi me unustada, et taevase üliolendi juurde on alati kuulunud äikesefunktsioon. See on olnud nii Kunda kultuuri naabritel Euroopa substraatkultuuris ja veelgi ilmsemalt torkab ta silma indoeuroopa usundikihis juba vanimatest aegadest peale. Niisiis tuleb seda otsida ka eesti muinasusundist. Küsimus on muidugi selles, kuivõrd selgelt võib äikesefunktsiooni eristumist vanimatel aegadel üldse täheldada.

Kui Ivar Paulson kirjutab, et hilisemas rahvausundis on harva juttu piksele ohverdamisest (Paulson 1966: 113-115), ei tähenda see veel, nagu oleks äikesekultus olnud vähetähtis. Pigem võib arvata mingil põhjusel muistse äikesejumalakujutluse taandumist. Säilinud on ta teatud määral muistse väe- ja viljakuskultuse osana kui loodusvaimu austamine koos talle ohverdamisega. U. Masing ei pea Uku kultust Eestiski võimatuks, sest Soomest on Ukko kohta teateid ju 1551. aastast Mikael Agricolalt (Masing 1995: 45). Nüüdisaja tuntud usundiloolane Günther Lanczkowski mainib sa- 


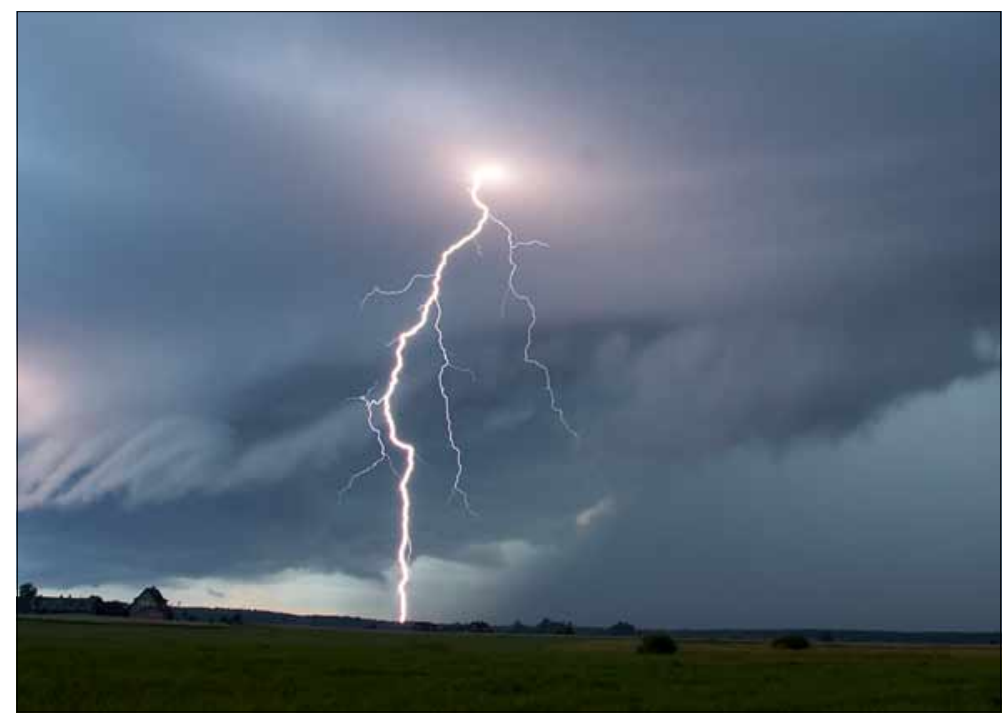

Foto 2. Äike kui võimas ja seletamatu loodusnähtus on ärgitanud paljusid rahvaid samastama äikesejumalat ülijumalaga. Äike LõunaEestis 2005. aasta suvel. Sven Začeki foto.

muti eestlaste äikesejumalana Pikset ja soomlastel Ukkot, vadjalastel Inmarit, maridel Jumot, sürja-komidel Jevit ja mordvalastel Škajd, kusjuures alates vadjalastest tähendab jumalanimi taevast, jumalat või loojat, eestlastel ja soomlastel on Pikne ja Ukko seotud aga äikesenähtustega (Lanczkowski 1989: 106-107). Selline tähenduste erinemine viib mõttele, et eestlastel ja soomlastel võib olla taevajumala äikesefunktsioon teataval määral selgemalt eristunud.

Põhjalikult kirjeldab äikesega seotud uskumusi eesti usundis O. Loorits (1951: 7-40). Ta arvab, et varasemad soome-ugri usundikihistused ei pööranud äikesele erilist tähelepanu, see olevat olnud pigem inimese hingelinnu üks ilmumisvorm kõuelinnu, ilmalinnu või taevalinnuna. Kõuemürina kohta on öeldud, et taevakivid mürisevad. Taevatule austamine olevat samuti hilisem aarja usundilaen. Äikest nimetatakse Eestis erinevalt. Põhja-Eestis ja Saaremaal on ta kõu, eriti Kirde-Eestist on tulnud nimetus äike (vrd soome äijä). Soome laen Ukko on Viru rannikul tuntud ukuna. LõunaEestis ja Hiiumaal on äikesele nimeks antud vanem, vanaisa, tae- 


\section{Tarmo Kulmar}

vaisa. Äikest nimetatakse ka impersonaalselt - müristab, lööb väl$k u$. Kõu jälitab kuradit, kurat kardab välku ja hunti; hunt on äikesejumala loom. Täheldatav on tule ja vee kontrast - äike lööb vette, eriti, kui kurat sinna peitu poeb.

O. Loorits arvab ka, et vetevaim on vaheastmeks kurja surnu ja dualistliku kuradi vahel. Äikesega seostatud haamer ja kirves on germaani äikesejumala sümbolid. Motiiv varastatud ja tagasi saadud Pikse pillist arvatakse olevat laen balti mütoloogiast. Paljud äikesejumala kui kaitsevaimu funktsioonid on Eestis kaotsi läinud, säilinud on mõned viljakuskultuslikud jooned: äike viljastab kevadeti maad, ohvriks tuuakse piima, eesti folklooris teatakse kindlasõnalisi loitse. Äikesega on seotud vikerkaar (pikkerkaar) - äikesejumala vöö. Sidet Thoriga näitab nimi Tooru (Harju-Madisel toorujumal, Läänemaa kihelkondades tooru-mees). Tuntud on nn tooruõhtu pühitsemine neljapäeval. Äikesejumala puu on tamm.

Oskar Looritsa kirjeldus toetub enamasti muidugi folkloorsele ainesele, mistõttu tuleb suur osa sellest kirjeldusest vaatluse alt välja jätta kui võrdlemisi hiline. Mõningatele joontele peaks siiski tähelepanu pöörama. Esiteks oleks väär arvata, et varasemad soome-ugri usundikihistused äikesele vähe austust oleksid osutanud, sest äike on ikkagi üliolendi üks peamisi funktsioone ja tajutav peaaegu kõigi meeleorganite vahendusel. Nagu näitab megaliitkultuuri uurimine, on äike üks taevajumala viljakusega seotud tunnusjooni ja seega tähtis kultusobjekt. Veelgi olulisem roll oli äikesel indoeuroopa usundis - lisaks viljakusfunktsioonile oli tal kurjaga võitlejana täita jõufunktsioon. Vaevalt et kõuelind oleks olnud üks hingelinnu ilmumisvorme, pigem on lind ju kas või Wilhelm Schmidti fenomenoloogiat jälgides üliolendi saatjaid.

Kas tule austamine tingimata just aarja usundilaen peaks olema, kuigi tulekultus on indoeuroopa usundis oluline olnud, on samuti kaheldav. Et tuli on uurali kihistusse kuuluv sõna, võib ta oma paljutähenduslikkuse tõttu olla seotud nii ohvri kui ka taevase väe - äikesega. Tuld aitab ülijumalaga/üliolendiga siduda ka W. Schmidti materjal.

Mis äikeseolendi nimedesse puutub, siis Vanaisa, Taevaisa jt analoogilised nimed on kindlasti omapäritolu, sest nii kutsutakse üliolendit kogu maailmas, nagu taas nägime W. Schmidti tööde põhjal. Seevastu Kõu, Äike ja Pikken/Pikne/Pikker paistavad olevat vanad balti laenud. $K \tilde{u} u(k)$, soome kouko taga on ilmselt balti usundiilma väikesed üleloomulikud olevused nimega kaukai, kes 


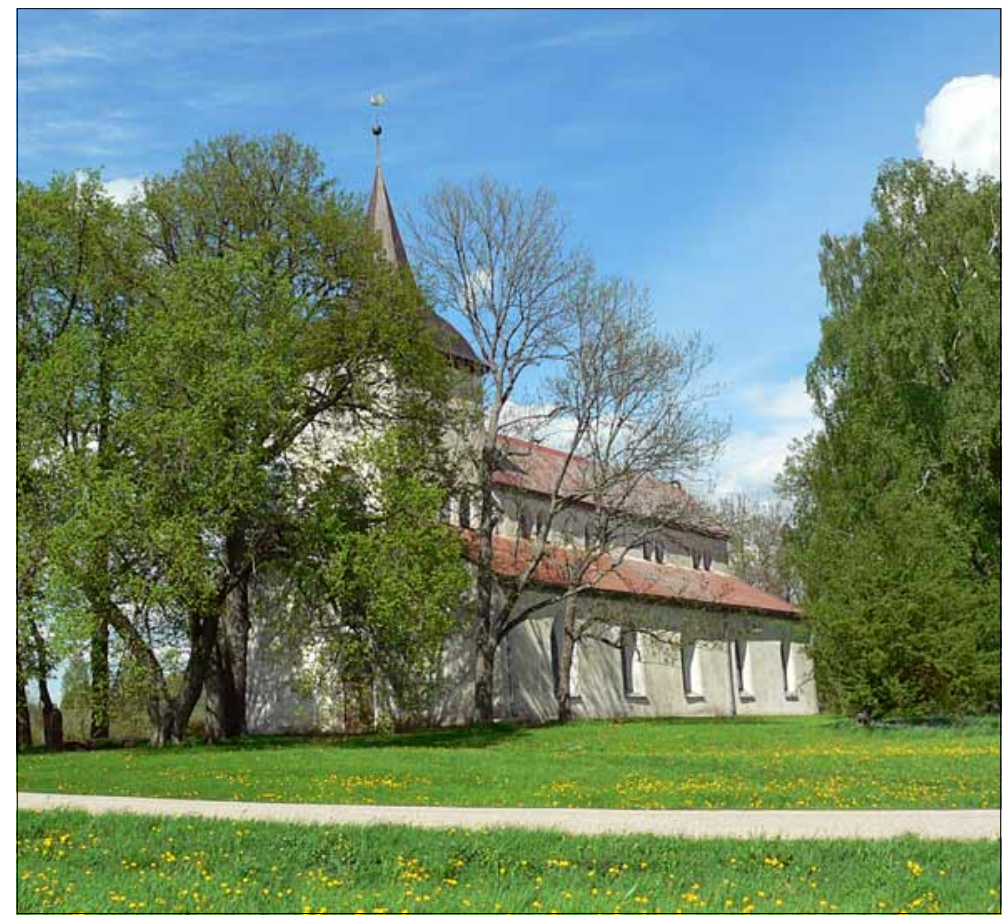

Foto 3. Jumala poole palvetatakse, ka äikesejumala poole. Pildil olevas Urvaste kirikus teenis aastatel 1630-1656 Johann Gutslaff, kes avaldas oma 1644. aastal ilmunud raamatus Kurtzer Bericht vnd Unterricht Von der Falsch-heilig genandten Bäche in Lieffland Wöhhanda muu hulgas ka Erastvere talupojalt Vihtla Jürgenilt kuuldud piksepalve (Voda Picker). Andres Kuperjanovi foto 2005.

uluvad ja näuguvad (verb kaukti 'karjuma, uluma, näuguma') - piksejumal Perkūnas/Pērkuns muutis oma vastaseid näuguvateks kassideks. Sellisena kujutab L. Vaba ette kõue geneesi kaugeid tagamaid (Vaba 1993: 509). Äike võib olla seotud leedu metsa- ja kodujumalustega aitvaras, kellega Perkūnas samuti võitleb. Vahel kujutati neid ette tulelohedena (Vaba 1993: 509). Pik(k)ne tundub samuti olevat balti laen läänemeresoome keelde (Mägiste 19821983 VII: 2042).

Äikese nimetamine impersonaalselt (müristab) võib ühelt poolt olla seotud ürgsete väekujutlustega, teiselt poolt lubab juurde mõeldav isik ( $t a$ ) oletada just vastupidi kunagist rõhutatud personaal- 


\section{Tarmo Kulmar}

sust, mis on hiljem kaotsi läinud. Selles punktis on raske selgust luua.

Vasar on eespool vaadeldud P. Ariste etümoloogia järgi indoiraani laen soome-volga perioodist. See on kindlamaid tunnusmärke äikesefunktsiooni eraldumisest hiljemalt III aastatuhandel eKr, sest kõuekivid, kivikirved ja -vasarad on äikesesümboliteks olnud mitte ainult indoeuroopa, vaid ka protoeuroopa usundis, nagu on näidanud Johannes Maringer (1956: $293 \mathrm{jj}$ ). Seega ei ole haamer ja kirves kindlasti germaani laenud, nagu oletab O. Loorits, vaid tunduvalt varasemad.

Pikse pilli motiiv võib olla nii balti kui ka germaani laen. Vastavate eesti ja soome teemadega on tutvunud Jan de Vries, kes arvab selle motiivi olevat põhjaskandinaavia usundilaenu (Vries 1937: 217). Kui see oleks balti laen, siis ilmselt varajasem. Igatahes eriti vana motiiv see ei ole.

Vikerkaare seost üliolendiga vaatlesime samuti eespool. Muidugi võib vikerkaar olla samahästi ühenduses ka äikesefunktsiooniga.

Tooru, neljapäeva (Donnerstag, Thorstag) pühitsemine ja võibolla et ka tamme austamine osutavad muidugi sidemetele Thori kultusega. See võib olla pärit viikingiajast, kuid võimatud ei ole ka mingil määral toimunud kokkupuuted varajasel metalliajal.

Äikesejumala viljakuskultuslikud jooned on üldlevinud kui fenomenoloogiline reegel, mistõttu ei ole põhjust neid otseselt laenudeks pidada. Teatud elementide vahetamine äikesega seotud viljakuskultuste vahel võib loomulikult võimalik olla.

Unto Salo on uurinud ovaalsete tulekivide levikuala seost äikesekultusega ja määratlenud ala, mis hõlmab Skandinaavia, Taani, Baltikumi ja Soome, seega piirkonna, kus üliolendikultuses on eristunud äikesefunktsioon. Äikesejumalakujutluse erinevaid variatsioone leidub kogu läänemeresoome kultuuriruumis. Soome osas arvab U. Salo, et äikesejumal Ukko ulatub tagasi pronksiaegsesse Kiukaiste kultuuri, seega varajasse läänemeresoome aega (Salo 1990: 49-61). Siinkirjutaja on Eesti osas küll seisukohal, et eraldunud äikesefunktsioonist võib kõnelda juba indoeuroopaliku nöörkeraamikakultuuri puhul, keeleajalooliselt aga hiljemalt soome-volga ajast. Varajasematel kihistustel ei tarvitsenud äikesejumal ei soome-ugri ega ka substraatses kultuuriruumis veel oluliselt üliolendist eraldunud olla. Üliolendi ühe olulisema funktsioonina teda aga kindlasti austati ka soome-permi ajastul ja vast varemgi. 
Niisiis on läänemeresoome hõimude muistset taevast üliolendit juba ainuüksi eespool toodud etnoloogilise, keeleteadusliku ja arheoloogilise ainese alusel võimalik üpris veenvalt ette kujutada.

\section{Kirjandus}

Achelis, Thomas 1919. Die Religionen der Naturvölker im Umriss. Sammlung Göschen 449. Leipzig \& Berlin: Vereinigung Wissenschaftlicher Verleger.

Ariste, Paul 1981. Keelekontaktid: Eesti keele kontakte teiste keeltega. Eesti NSV TA Emakeele Seltsi Toimetised 14. Tallinn: Valgus.

Eliade 1987 = Элиаде, Мирча. Шаманизм и космология. Космос и история: Избранные работы. Москва: Прогресс, lk 154-158.

Eliade, Mircea 1992a-1992i. Sakraalne ja profaanne: Religiooni olemus. Vikerkaar 4, lk 52-58; 5, lk 78-82; 6, lk 65-69; 7, lk 65-70; 8, lk 73-80; 9, lk 67-75; 10, lk 58-63; 11, lk 65-70; 12, lk 73-78.

Heiler, Friedrich 1979. Erscheinungsformen und Wesen der Religion. Die Religionen der Menschheit 1. Stuttgart: Verlag W. Kohlhammer.

Henrik 1992 = Henriku Liivimaa kroonika. Kleis, Richard (tõlk) \& Tarvel, Enn (toim \& komment). Tallinn: Eesti Raamat.

Herrmann, Ferdinand 1961. Symbolik in den Religionen der Naturvölker. Symbolik der Religionen 9. Stuttgart: Anton Hiersemann.

Hiärne, Thomas 1963. Eestlaste uskumustest ja kommetest. Laugaste, Eduard (koost). Eesti rahvaluuleteaduse ajalugu: Valitud tekste ja pilte. Tallinn: Eesti Riiklik Kirjastus, lk 71-75.

Koivulehto, Jorma 1991. Uralische Evidenz für die Laryngaltheorie. Sitzungsberichte. Österreichische Akademie der Wissenschaften: Philosophisch-Historische Klasse 566. Veröffentlichungen der Komission für Linguistik und Kommunikationsforschung 24. Wien: Verlag der Österreichische Akademie der Wissenschaften.

Lanczkowski, Günther 1989. Geschichte der nichtchristlichen Religionen. Fischer-Taschenbücher 4564. Fischer-Lexikon. Frankfurt am Main: Fischer Taschenbuch Verlag.

Loorits, Oskar 1949. Grundzüge des estnischen Volksglaubens I. Skrifter Utgivna av Kungl. Gustav Adolfs Akademien för Folklivsforskning 18. Lund: Blom.

Loorits, Oskar 1951. Grundzüge des estnischen Volksglaubens II. Skrifter utgivna av Kungl. Gustav Adolfs Akademien för folklivsforskning 18. Lund: Blom. 


\section{Tarmo Kulmar}

Maringer, Johannes 1956. Vorgeschichtliche Religion: Religionen im steinzeitlichen Europa. Einsiedeln et al.: Benziger.

Masing, Uku 1995. Eesti usund. Tartu: Ilmamaa.

Mägiste, Julius 1982-1983. Estnisches etymologisches Wörterbuch I-XII. Helsinki: Finnisch-Ugrische Gesellschaft.

Oinas, Feliks 1981. Jumi a Fertility Divinity. Ikola, Osmo (toim). Congressus Quintus Internationalis Fenno-Ugristarum, Turku 20.-27. VIII 1980 8: Dissertationes sectionum: Ethnologica, folkloristica et mythologica, archaeologica et anthropologica. Turku: Suomen Kielen Seura, lk 256-261.

Paulson, Ivar 1966. Vana Eesti rahvausk: Usundiloolisi esseid. Stockholm: Vaba Eesti.

Rédei, Karoly 1986-1991. Uralisches etymologisches Wörterbuch 1-2, 5-8. Budapest: Akadémiai Kiadó.

Salo, Unto 1990. Fire-striking Implements of Iron and Finnish Myths Relating to the Birth of Fire. Iskos 9, lk 49-61.

Sayers, William 1990. Weather Gods Syncretism and the Eastern Baltic. Temenos: Studies in Comparative Religion 26, lk 105-114.

Schebesta, Paul 1927. Bei den Urwaldzwergen von Malaya. Leipzig: F.A. Brockhaus.

Schmidt, Wilhelm P. 1935. Der Ursprung der Gottesidee: Eine historischkritische und positive Studie 2: Die Religionen der Urvölker 6: Endsynthese der Religionen der Urvölker Amerikas, Asiens, Australiens, Afrikas. Münster: Aschendorffsche Verlagsbuchhandlung.

Schroeder, Leopold von 1906. Germanische Elben und Götter beim Estenvolke. Sitzungsberichte der philosophisch-historischen Klasse der Kaiserlichen Akademie der Wissenschaften: Philosophisch-Historische Klasse 153:1. Wien: Hölder.

Schroeder, Leopold von 1914. Einleitung, der altaische Himmelsgott, das höchste gute Wesen. Arische Religion 1. Leipzig: H. Haessel Verlag.

Vaba, Lembit 1993. Sõnavarauurija mõttemõlgutusi ühe mütoloogiaraamatu ilmumise puhul. Keel ja Kirjandus 8, lk 507-510.

Vries, Jan de 1937. Altgermanische Religionsgeschichte 2: Religion der Nordgermanen. Grundriss der germanischen Philologie 12: 2. Berlin-Leipzig: Walter de Gruyter. 